\title{
Feasibility and Risk Production of Shallot Farming in Demak, Central Java, Indonesia
}

\author{
Triyono $^{*}$, and Hastuti Sulistyaningsih \\ Department of Agribusiness, Universitas Muhammadiyah Yogyakarta, J1. Brawijaya, Kasihan, Bantul \\ Yogyakarta, Indonesia
}

\begin{abstract}
Shallot is a great prospect for farmers in Demak Regency. Shallot farmers in Demak Regency cultivated 2 different varieties which Bauji variety was claimed to be more profitable than the Bima variety. In addition it was known that there were differences in the treatment of the two varieties. The purpose of this study is to analyze feability and production risk of shallot farming. This research was conducted in Pasir Village and Kotakan Village, Demak Regency. Data collection was carried out by direct interview with 50 farmers by census and 50 farmer respondents randomly. To analyze, to use the formula of $\mathrm{R} / \mathrm{C}$, and coefficient of variation using the independent sample t-test method in the SPSS application. The results of the research showed that both farms were equally feasible to be cultivated, but the Bauji variety farming had a higher production risk than the bima variety.
\end{abstract}

\section{Introduction}

Shallots are one of the vegetable commodities that are prioritized in the development of vegetables in the lowlands in terms of their advantages quite strategic and economical [1]. This commodity has a bright prospect due to its nature which has no substitute [2]. Shallots are one of the commodities that will grow well in the lowlands. This is due to the characteristics of shallots that require sufficient light, which is at least 12 hours a day. The better the irradiation, the more potential results obtained will be maximized. In Indonesia, the largest shallot producing area is still concentrated on the island of Java. This can be seen from the BPS and the Directorate General of Horticulture in 2016 the province that contributed the most to the production of shallots was the province of Central Java. East Java and West Nusa Tenggara with total production of 546,585 tons, 304,521 tons, and 211,804 tons, respectively [3].

Based on Table 1, the largest shallot production center is in Central Java, located in Brebes with a productivity of 116.87 tons/ha, followed by Demak with a productivity of 102.25 tons/ha [3]. Productivity shows the average production on a certain land area. The higher the productivity, the higher the potential yields and profits. There are various types of varieties cultivated in Demak Regency, but the most widely cultivated are the Bima variety and the Bauji variety.

* Corresponding author: triyono@umy.ac.id 
Table 1. Harvested Area and Production of Shallots per Regency/City in Central Java,

\begin{tabular}{|l|r|r|r|}
\hline Regency/City & $\begin{array}{c}\text { Harvested Area } \\
\text { (ha) }\end{array}$ & $\begin{array}{c}\text { Production } \\
\text { (quintal) }\end{array}$ & Productivity (quintal/ha) \\
\hline Boyolali & 951 & 104,357 & 109.73 \\
\hline Grobogan & 563 & 53,296 & 94.66 \\
\hline Pati & 1,954 & 221,008 & 113.10 \\
\hline Demak & $\mathbf{4 , 7 8 3}$ & $\mathbf{4 8 9 , 0 5 3}$ & $\mathbf{1 0 2 . 2 5}$ \\
\hline Temanggung & 1,461 & 119,311 & 81.66 \\
\hline Kendal & 2,556 & 254,993 & 99.76 \\
\hline Tegal & 2,124 & 215,464 & 101.44 \\
\hline Brebes & 26,645 & $3,112,961$ & 116.87 \\
\hline
\end{tabular}

Both varieties have their respective advantages. The Bima variety is sensitive to late blight (Phytophtora porii) and quite resistant to tuber rot (Botrytis allii). This Bima variety is very well planted in the lowlands [4]. Bima variety shallots have good quality, distinctive taste and aroma, but the price of seeds is quite expensive, namely IDR $20,000 / \mathrm{kg}$. The Bauji variety can also be grown in the lowlands and is suitable for planting in the rainy season. For pest and disease resistance, this bauji variety is somewhat resistant to armyworm (Spodoptera exigua) and fusarium disease. The advantages of other bauji varieties are that they are able to produce around 13-14 tons per hectare and the price of onion seeds for the bauji variety is cheaper than the bima variety, which is IDR $12,000 / \mathrm{kg}$.

The existence of these differences makes the shallot farmers of the bauji variety feel benefited because when the harvest arrives the price of shallot of the bauji variety is able to compete with the bima variety. The thing that farmers do to keep competing to produce good seeds is in cultivation activities, namely fertilization. Onion Bauji farmers fertilize 4 times in 1 planting season, while for Bima variety farmers only do 3 times in 1 growing season with the same planting age of 60 days. Differences in production inputs will affect the costs to be incurred. Based on the problems described above, this study aims to analyze the feasibility of farming the bima and bauji varieties of shallots in Demak Regency. In addition, the study analyze the risk of shallot farming.

Research on the feasibility of onion farming has been carried out in previous studies. Research by [5] showed that the varieties of shallots of the hammer valley are feasible but risky. Meanwhile, the results of research conducted by [6] stated that onion farming in 3 planting seasons in three production center districts namely Cirebon, Brebes and Tegal was feasible. In the first harvest season in Trenggamus the farm was declared feasible[7]. Research shows that shallot cultivation using the TSS (True Shallot Seed) system shows that it is more feasible to cultivate with a productivity of 14.9 tons/ha, high productivity, and lower production costs [8]. The feasibility analysis using NPV, Net B/C, IRR, and Payback period conducted by [9] revealed that shallots farming are feasible to cultivate.

The results of research by [10] regarding the risk of shallot farming income in Bantul Regency revealed that the risk of shallot farming income is quite high at $72.7 \%$. This happens because the risk of shallot production is also high at $85.18 \%$ [11]. The factors that influence the level of risk are the number of workers, the use of NPK fertilizers and the use of pesticides [12]. In addition, the behavior of shallot farmers in the Palu Valley in Sigi Regency is risk averse and $30.32 \%$ are risk takers, and to get higher production farmers must take risks [13].

Based on the production risk map, it shows that the risk of shallot production faced by farmers is in the orange area which is included in the high risk category. The factors that affect the risk of off-season or off-season shallot farming production in Petak Village are 
liquid pesticides, while fertilizer, seed, labor and solid pesticides have no significant effect on the risk of shallot production [14].

Research related to climate states that weather and growing season are variables that affect the risk of shallot farming [15]. The growing season greatly affects shallot farming, especially shallot farming in the dry season which has higher risk). Another study stated that the risk of red onion farming in the dry season is higher than in the rainy season Yasa et al, 2013. Shallots are slow growing plants, shallow rooted plants with unshady habitus so that their productivity is highly dependent on availability. water in the soil, proper fertilization and weed control [16].Meanwhile other factors that affect the risk of shallot farming in the dry season are seeds and adhesives and in the rainy season it is influenced by female labor in the family, fertilizer Phonska, and NPK Mutiara [17].

\section{Research Method}

The basic methods used in this research are descriptive and analytical basic methods. Descriptive method is used to provide an overview of the costs, income, and profits obtained by the farmers of shallot bima and shallot bauji based on the facts obtained directly. The analytical method is used to determine the level of risk of shallot farming in Demak Regency by using the results that have been obtained.

Determination of the location was chosen intentionally (purposive sampling) based on a specific purpose [18]. This research is located in Mijen District and Karanganyar District, Demak Regency. This location was chosen because these two sub-districts have more total shallot production than the other 12 sub-districts. Meanwhile, determination of the sample of respondents in this study was carried out using a simple random sampling method, namely a sampling technique where sampling was carried out randomly [19]. The samples taken in this study were Pasir Village and Kotakan Village. Determination of the number of respondents was carried out using a census in Kotakan Village where in Kotakan Village there were 8 farmer groups and those who were active or frequently present in extension activities were only one group with 50 members. While in Pasir Village there are 7 farmer groups but only one group is active with 85 members and uses a simple random method, where 50 respondents have been taken. Then, Data collection techniques were carried out by direct interviews with respondent farmers with a questionnaire guide. This research was conducted on shallot farmers of the Bima variety and the Bauji variety in the third planting season in June-August 2019.

Feasibility can be interpreted as a measure to see whether a business being run will provide benefits or benefits that are greater than the costs to be incurred or this business does not have a profit so it is not worth working on [20]. Based on the statement above, feasibility can also be interpreted to test whether a business can be feasible or not. Business feasibility can be done using the $\mathrm{R} / \mathrm{C}$ approach. It is a measurement of the use of costs in the production process which is a comparison between total revenue and total costs [21]. It can be done with the following measurements:

Information:

$$
R / C=\frac{T R}{T C}
$$

TR : Total Revenue (IDR)

TC : Total Explicit and Implicit Cost (IDR)

There are three provisions in the $\mathrm{R} / \mathrm{C}$ ratio, that is :

If the $\mathrm{R} / \mathrm{C}>1$, then the farm is feasible to run.

If the $\mathrm{R} / \mathrm{C}=1$, then the farm is not profitable and does not lose or break even.

If the $\mathrm{R} / \mathrm{C}<1$, then the farm is not feasible to run. 
Risk in farming is caused by several factors, among others. factors of production, land area. Weather, and farmer experience. Farmers in doing business face problems both internal and external. One example of an internal problem is land tenure, the low quality of labor, while an external problem is an uncertain climate. These problems can pose a risk to farmers [10].

The risk analysis of farming can use the coefficient of variation $(\mathrm{CV})$, where the greater the value $(\mathrm{CV})$, the greater the risk borne by farmers. The relationship between risk and production is something important in farming. This relationship can be measured by the coefficient of variation or the lowest level of risk. According to [22] the coefficient of variation or the lowest level of risk is a comparison between the risk that must be borne by farmers and the amount of production to be obtained.

The Coefficient of Variation is a measurement of relative risk obtained by dividing the standard deviation by the expected mean value [23]. The coefficient value is formulated as follows:

Information:

$$
\mathrm{CV}=\frac{\sigma}{\mathrm{E}}
$$

$\mathrm{CV}=$ Coefficient of variation

$\sigma=$ standard deviation

$\mathrm{E}=$ average production $(\mathrm{kg})$

\section{Results and Discussion}

\subsection{Feasiblity Shallot Farming}

Feasibility of farming is used to measure whether the farm is feasible to run or not. The calculation of the feasibility of farming can be done by using the $\mathrm{R} / \mathrm{C}$ ratio. $\mathrm{R} / \mathrm{C}$ or Revenue Cost Ratio is a comparison between the total revenue and the total costs incurred by the shallot farmers of the bima and bauji varieties. In the application of $\mathrm{R} / \mathrm{C}$, farming is said to be feasible if the $\mathrm{R} / \mathrm{C}$ value $>1$, whereas if farming is said to be unfeasible if the $\mathrm{R} / \mathrm{C}$ value $<1$.

Table 2. R/C value of shallot farming of bima and bauji varieties

\begin{tabular}{|l|r|r|r|r|}
\hline \multirow{2}{*}{ Information } & \multicolumn{2}{|c|}{ Bima Variety } & \multicolumn{2}{c|}{ Bauji Variety } \\
\cline { 2 - 5 } & Per house hold & Per ha & Per hose hold & \multicolumn{1}{c|}{ Per ha } \\
\hline Total Revenue (IDR) & $56,851,920$ & $141,112,471$ & $75,734,000$ & $210,662,934$ \\
\hline Total Cost (I DR) & $20,568,474$ & $52,954,840$ & $20,078,475$ & $47,256,302$ \\
\hline R/C & $\mathbf{2 . 7 6}$ & $\mathbf{2 . 6 6}$ & $\mathbf{3 . 7 7}$ & $\mathbf{4 . 4 6}$ \\
\hline t-test =-6,413** & & & \\
\hline t- table =1,98 & & & & \\
\hline
\end{tabular}

Information : ** significant at $\alpha=5 \%$

Based on Table 2, it shows that the cultivation of shallots of the Bima and Bauji varieties is feasible and profitable. In the red onion farming of Bima variety, the $\mathrm{R} / \mathrm{C}$ value of 2.76 means that for every IDR 1 of the costs incurred, the farmer will get an income of IDR 2.76. As for the shallot farming of the bauji variety, the $\mathrm{R} / \mathrm{C}$ value is 3.77 , which means that for every IDR 1 of the costs incurred, the farmer will get an income of IDR 3.77 from the farming run. This result is higher than the shallot farming in other locations outside Java [24]. The feasibility of onion farming is relatively higher when compared to cereal commodities such as corn with an $\mathrm{R} / \mathrm{C}$ value of less than two [25]. 
The difference in feasibility between the bima and bauji varieties based on the average difference test of the $\mathrm{R} / \mathrm{C}$ value shows that the $\mid \mathrm{t}$-test $\mid$ value $>\mathrm{t}$-table that is equal to $6.413>$ 1.98 with an error rate of 0.05 which means that $\mathrm{H}_{0}$ is rejected and $\mathrm{H}_{1}$ is accepted, indicating a significant difference in the level of farming feasibility between the bima and bauji varieties, namely the farming feasibility of the bima variety is lower than the bauji variety.

\subsection{Risk Production of Shallot Farming}

The risk of farming shallots of the Bima and Bauji varieties can be measured using the calculation of the coefficient of variation which is obtained by dividing the standard deviation by the expected average value [23]. The risk assessment of shallot farming of Bima and Bauji varieties used an average land area of 3,876 $\mathrm{m} 2$ and 4,946 $\mathrm{m} 2$. This is so that the risk calculation can be presented in a real way without the influence of land area.

In running a farm, farmers want to get maximum production results. However, natural conditions, pest and disease attacks cause possible bad consequences so that they will affect the production results that will be obtained by farmers. Risk can be interpreted as an unexpected event due to losses and uncertainties that arise [26]. revealed that the risk most often occurs in the agricultural sector which makes farmers' incomes decline. These risks can come from production, prices, farmers, finance, and institutions or the government [27]. The risk of the shallots production of the bima and bauji varieties can be seen in table 3 below.

Table 3. Production risk of bima and bauji varieties shallots

\begin{tabular}{|l|r|r|r|r|}
\hline \multirow{2}{*}{ Information } & \multicolumn{2}{|c|}{ Bima Variety } & \multicolumn{2}{c|}{ Bauji Variety } \\
\cline { 2 - 5 } & Per household & Per ha & Per hpusehold & Per ha \\
\hline Production $(\mathrm{kg})$ & 3,372 & $8,369.66$ & 3,986 & $10,897.05$ \\
\hline Standard Deviation & $1,888.10$ & $1,180.07$ & $2,375.04$ & $13,205.33$ \\
\hline Coefficient Variation $(\mathrm{CV})$ & 0.56 & 0.14 & 0.60 & 1.19 \\
\hline
\end{tabular}

Based on Table 3, it shows that the production risk of the bauji variety is greater than the production risk of the Bima variety on the average land area per 1 ha, which is 1.19 or $119 \%$. This means that for every $1 \mathrm{~kg}$ of production received by shallot farmers of the bauji variety, the production risk faced by farmers is $1.19 \mathrm{~kg}$. Meanwhile, the Bima variety shallot farmers with the same land area, which is per 1 ha, the production risk is 0.56 or $56 \%$. This means that for every $1 \mathrm{~kg}$ of production produced by shallot farmers of the Bima variety, the production risk faced by farmers is $0.56 \mathrm{~kg}$. The varietal differences show a high diversity in yield and chemical properties of the onion varieties studied [28].

The results of this study indicate that varieties affect the production of shallots cultivated by farmers. In addition, the growing season factor; late planting; increased use of minimum technology; poor nursery and agricultural management practices, insect diseases and pests; Poor harvesting and post-harvest practices contribute to poor shallot yields and limit commercial onion farming [29].

\section{Conclusions and Recommendations}

Shallot farming of bauji and bima varieties is feasible. The bauji variety has a higher feasibility level than the bima variety of shallot farming. However, the production risk of the bauji variety shallot farming is higher than that of the Bima variety shallot. Base on it, farmers should choose the bauji variety to cultivate because it has a higher feasibility value. 
Farmers who cultivate shallots of the bauji variety need to apply appropriate farming practices to reduce production risk.

\section{References}

1. D. Nur Asih. Analisis Karakteristik dan Tingkat Pendapatan Usahatani Bawang Merah di Sulawesi Tengah. J. Agrol. 16, 53 (2009).

2. L. Rahmadona, A. Fariyanti, and B. Burhanuddin. Analisis Pendapatan Usahatani Bawang Merah Di Kabupaten Majalengka. J. AGRISE XV, 72 (2015).

3. BPS, Luas Panen Dan Produksi Bawang Merah Di Jawa Tengah (Semarang, 2016).

4. N. Waluyo and R. Sinaga. Bawang Merah Yang Dirilis Oleh Balai Penelitian Tanaman Sayuran. IPTEK Tanam. Sayuran No. 005, (2015).

5. A. A. Rustam Abd Rauf, Saiful Darman. Pengembangan Usahatani Bawang Merah Varietas Lembah Palu Dan Strategi Analisis Swot. Agriekonomika 4, 245 (2015).

6. H. F. Aldila, A. Fariyanti, and N. Tinaprilla. Analisis Profitabilitas Usahatani Bawang Merah Berdasarkan Musim Di Tiga Kabupaten Sentra Produksi Di Indonesia. SEPA J. Sos. Ekon. Pertan. Dan Agribisnis 11, 249 (2017).

7. R. Kesuma, W. A. Zakaria, and S. Situmorang. Analisis Usahatani Dan Pemasaran Bawang Merah Di Kabupaten Tanggamus. (Analysis Onion Farm Mark. Tanggamus Regency) 4, 1 (2016).

8. H. S. RAHAYU, M. MUCHTAR, and S. SAIDAH. The feasibility and farmer perception of true shallot seed technology in Sigi District, Central Sulawesi, Indonesia. Asian J. Agric. 3, 16 (2019).

9. D. Fajarika, R. U. Fahadha, I. Mardiono, and N. Miswari. Feasibility Study of Shallot Production in Financial Aspect in Central Lampung (Case Study : Kota Gajah). J. Sci. Appl. Technol. 2, 26 (2019).

10. M. Fauzan. Pendapatan, Risiko dan Efisiensi Ekonomi Usahatani Bawang Merah di Kabupaten Bantul. Agrar. J. Agribus. Rural Dev. Res. 2, 107 (2016).

11. M. Lawalata. Risiko Usahatani Bawang Merah di Kabupaten Bantul. J. Agrica 10, 56 (2017).

12. R. Mutisari and D. Meitasari. Analisis Risiko Produksi Usahatani Bawang Merah di Kota Batu. J. Ekon. Pertan. Dan Agribisnis 3, 655 (2019).

13. Erny, D. H. Darwanto, Masyhuri, and L. R. Waluyati. Farmer's behavior towards lembah palu shallot farm risks in central sulawesi, Indonesia. EurAsian J. Biosci. 13, 931 (2019).

14. M. R. Ghozali and R. Wibowo. Analisis Risiko Produksi Usahatani Bawang Merah di Desa Petak Kecamatan Bagor Kabupaten Nganjuk. J. Ekon. Pertan. Dan Agribisnis 3, 294 (2019).

15. F. Hasan, D. H. Darwanto, Masyhuri, and W. Adiyoga. Risiko Produksi dan Perilaku Petani Menghadapi Risiko Usahatani Bawang Merah di Kabupaten Nganjuk. Inisiasi 7, 211 (2018).

16. A. Sekara, R. Pokluda, L. Del Vacchio, S. Somma, and G. Caruso. Interactions among genotype, environment and agronomic practices on production and quality of storage onion (Allium cepa L.) - A review. Hortic. Sci. 44, 21 (2017).

17. L. T. W. Astuti, A. Daryanto, Y. Syaukat, and H. K. Daryanto. Analisis Resiko Produksi Usahatani Bawang Merah pada Musim Kering dan Musim Hujan di Kabupaten Brebes. J. Ekon. Pertan. Dan Agribisnis 3, 840 (2019). 
18. Suryabrata, Metode Penelitian (Raja Grafindo Persada, Jakarta, 2003).

19. Sugiyono, Metode Penelitian Bisnis, 7th ed. (Alfabeta, Bandung, 2009).

20. P. Pratama. Analisis Pendapatan Dan Kelayakan Usahatani Padi Sawah Di Desa Sidondo 1 Kecamatan Sigi Biromaru Kabupaten Sigi. Agrotekbis 2, (2014).

21. Soekartawi, Analisis Usahatani (UI Press, Jakarta, 2002).

22. S. Agustina, Ilmu Usaha Tani, 1st ed. (Malang, 2011).

23. J. . Pappas and R. Hirschey, Ekonomi Manajerial (Terjemahan) (2015).

24. K. Parinsi. Analisis Pendapatan Usaha Tani Bawang Merah Di Desa Singki Kecamatan Anggeraja Kabupaten Enrekang. J. Econ. 5, 193 (2017).

25. P. Sulistyaning Dyah and N. Kahfi. Feasibility Study of Hybrid Corn and Sweet Corn Farm in Plemahan District, Kediri Regency. E3S Web Conf. 232, 1 (2021).

26. Sriyadi, Risiko Usahatani, 1st ed. (Lembaga Penelitian, Publikasi \& Pengabdian Masyarakat (LP3M) Universitas Muhammadiyah Yogyakarta, Yogyakarta, 2014).

27. J. L. Harwood, R. Heifner, K. Coble, J. Perry, and A. Somwaru, Managing Risk in Farming: Concepts, Research, and Analysis (1999).

28. M. R. Pérez, N. Merkt, S. Zikeli, and C. Zörb. Quality aspects in open-pollinated onion varieties from Western Europe. J. Appl. Bot. Food Qual. 91, 69 (2018).

29. S. Akrofi, D. A. Kotey, E. N. Ahiatsi, and S. Larbi-Koranteng. Onion Farming Practices in Eastern Region of Ghana : Implications for Research. Asian J. Agric. Food Sci. 04, 2321 (2016). 